\title{
Zastosowanie zrobotyzowanego systemu QIROX do realizacji specjalnych procesów spawalniczych
}

\author{
The use of QIROX robotic system \\ for special welding processes
}

\section{Streszczenie}

W artykule przedstawiono unikatową odmianę metody spawania MAG puls ze zmienną polaryzacją łuku - proces ColdWeld. Omówiono charakterystykę przebiegu tego procesu oraz występujące w nim zjawiska cieplne. Wskazano głównie obszary jego zastosowania, a także korzyści wynikające z wdrożenia tego procesu do produkcji.

Słowa kluczowe: proces ColdWeld, polaryzacja łuku, składowa ujemna

\begin{abstract}
The article presents a unique welding method (MAG pulse with a changing arc polarity - the ColdWeld process). Describes the characteristics of this process and its thermal phenomena. Also shows benefits and main areas of implementation of this process in production
\end{abstract}

Keywords: Cold Weld process, arc polarization, minus factor

\section{Wstęp}

Zrobotyzowane systemy spawalnicze Qirox to kompletne rozwiązanie obejmujące robota, peryferia, sensory, oprogramowanie oraz technikę spawalniczą, dzięki czemu znajdują one szerokie zastosowanie we wszystkich gałęziach przemysłu metalowego, wykorzystujących do łączenia metali standardowe i specjalne procesy spawalnicze. Dla każdego zadania system Qirox oferuje odpowiednio dopasowane komponenty, co pozwala osiągnąc efekt końcowy w postaci zrobotyzowanej aplikacji spawalniczej (pojedynczego stanowiska lub linii technologicznej) optymalnie skonfigurowanej, osiągającej najwyższe wydajności produkcyjne przy zachowaniu wysokiej jakości złączy spawanych. Do realizacji zadań spawalniczych, w których do łączenia metali potrzebny jest proces lutospawania MIG/MAG, spośród wielu technologii spawalniczych dostępnych w systemie Qirox, najkorzystniejszym rozwiązaniem jest zastosowanie unikatowego procesu spawania ColdWeld.

W niniejszym referacie przedstawiono zasadę procesu ColdWeld oraz jego zalety ze szczególnym uwzględnieniem zastosowania w lutospawaniu.

\section{Opis procesu}

Celem badań było określenie wpływu składu chemicznegProces ColdWeld jest odmianą spawania pulsacyjnego metodą MIG/MAG, w którym zastosowano zmienną polaryzację łuku spawalniczego. Jest on dostępny tylko na urządzeniu Qineo Champ, którego układ sterowania, w sposób automatyczny, według zaprogramowanego algorytmu, przełącza tor mocy zmieniając biegunowość w zewnętrznym obwodzie spawania. Zmiana polaryzacji z dodatniej na ujemną (po stronie elektrody topliwej) następuje bezpośrednio po fazie bazowej i odbywa sie z jednoczesnym wygenerowaniem "ujemnego" impulsu prądowego z odpowiednio dobraną amplitudą i czasem jego trwania. Następnie odbywa się zmiana polaryzacji oraz zostaje wygenerowany dodatni impuls prądowy. Dokładny przebieg spawania pulsacyjnego ze zmienną polaryzacją przedstawia rysunek 1.

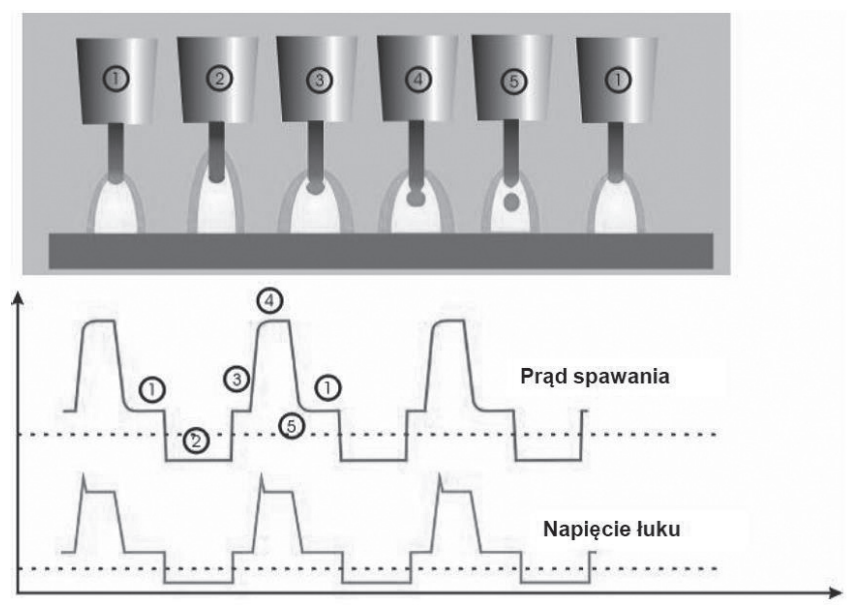

Rys. 1. Przebieg spawania ze zmienną polaryzacją łuku Fig. 1. Welding process with alternate arc polarization

Mgr inż. Andrzej Nieroba, Mgr Marcin Siennicki - Cloos-Polska, Dr inż. Krzysztof Kudła - Politechnika Częstochowska. Autor korespondencyjny/Corresponding author. a.nieroba@cloos.pl 
Wprowadzenie składowej ujemnej, do przebiegu spawania impulsowego metodą MIG/MAG, pozwoliło na wykorzystanie znanych własności spawania z odwrotną polaryzacją w postaci znacznie większej prędkości stapiania elektrody oraz mniejszej ilość ciepła skupionego w materiale podstawowym.

Sama zmiana biegunowości na elektrodzie z plusa na minus nie daje zadowalających efektów w procesie spawania, gdyż łuk jest niestabilny, a transport materiału z elektrody do jeziorka ciekłego metalu ma charakter grubo kroplowy z dużym rozpryskiem. Podobne efekty można zaobserwować przy zastąpieniu jednokierunkowego przebiegu prądu spawania, przebiegiem o charakterystyce sinusoidalnej, gdzie przy ponownych zapłonach łuku występują znaczne zakłócenia podczas spawania elektrodą topliwą. Dopiero w pełni programowalny przebieg spawania impulsowego, z asymetrycznym dwukierunkowym impulsem prądowym, całkowicie wykorzystuje zjawiska cieplne zachodzące w łuku spawalniczym i pozwala nimi sterować. W procesie ColdWeld można wyróżnić trzy zasadnicze fazy przebiegu natężenia prądu spawania i napięcia łuku: faza ujemnej biegunowości, dodatni impuls prądowo-napięciowy oraz faza bazowa. Natężenie prądu spawania i napięcia łuku przebiegają synchronicznie w tym samym kierunku przyjmując odpowiednio zaprogramowane wartości.

W czasie trwania ujemnej fazy procesu większa część ciepła łuku spawalniczego wydziela się po stronie drutu elektrodowego, co zwiększa szybkość jego stapiania przygotowując go do właściwego wytworzenia i oderwania kropli. W tej fazie procesu można zaobserwować rozproszenie łuku spawalniczego, które może prowadzić do jego destabilizacji. Dlatego też faza ujemna nie powinna trwać zbyt długo, a jej amplituda nie może być zbyt duża.

Dodatni impuls prądowy, ma za zadanie utworzenie na końcu drutu elektrodowego kropli ciekłego metalu i oderwanie jej. W tym obszarze decydującym czynnikiem powodującym oderwanie kropli ciekłego metalu z końca drutu elektrodowego, jest wielkość natężenia prądu spawania [1]. Prąd płynąc po pobocznicy drutu elektrodowego wywołuje ściskanie uplastycznionego i roztopionego końca drutu tworząc efekt przewężenia, gdzie oddziaływanie elektrody- namiczne, które jest wprost proporcjonalne do kwadratu natężenia prądu, odrywa i odrzuca krople ciekłego metalu w kierunku jeziorka spawalniczego. Stąd impulsy prądowe w urządzeniach Cloos mają bardzo dużą wartość impulsu prądowego przy stosunkowo krótkim czasie jego trwania. Po impulsie prądowym następuje faza prądu bazowego, w której odbywa się transport kropli metalu do jeziorka spawalniczego. Następnie proces się powtarza.

Warto zwrócić uwagę na fakt, że do wygenerowania tak zaawansowanego przebiegu prądowego z dynamiką prądową na poziomie $2000 \mathrm{~A} / \mathrm{ms}$ potrzebny jest zasilacz łuku spawalniczego, zbudowany z najnowocześniejszych układów energoelektronicznych, zdolnych do przełączania toru mocy w ekstremalnie krótkim czasie (kaskada tranzystorowa). Na rysunku 2 przedstawiono zarejestrowany, rzeczywisty przebieg spawania ColdWeld. Równe, idealnie powtarzalne impulsy prądowe i napięciowe, bez śladu zakłóceń, odzwierciedlają bardzo stabilny przebieg spawania impulsowego ze zmienną polaryzacją tuku.

Ten skomplikowany przebieg procesu spawania impulsowego można jeszcze modyfikować wprowadzając dodatkowe fazy np. pogłębiony impuls po stronie ujemnej albo stopniowany impuls po stronie dodatniej. Należy jednak pamiętać, że za właściwie zaprogramowany przebieg prądu i napięcia spawania uważa sie taki, który zapewnia oderwanie co najmniej jednej kropli w czasie jednego impulsu prądowego [4]. Zachowanie tego warunku zapewnia stabilne palenie się łuku spawalniczego, przy czym dla różnych rodzajów stopiw będą potrzebne różny zestawy parametrów opisujących impulsowy łuk spawalniczy oraz różne kształty impulsów [2]. Wszystkie te parametry są zapisane w układzie sterowania urządzenia Qineo Champ w postaci synergicznych charakterystyk spawalniczych ColdWeld dla różnych zestawów deskryptorów (rodzaj materiału spawanego, średnica elektrody, rodzaj gazu osłonowego, odmiana spawania itp.). Użytkownik ma więc możliwość zmiany mocy łuku spawalniczego, a zarazem wydajności spawania za pomocą jednego pokrętła. Dodatkowo, niezależnie od wielkości głównej nastawy parametrów, możliwa jest zmiana wartości składowej ujemnej w asymetrycznym dwukierunkowym przebiegu impulsowym. Na głównym ekranie

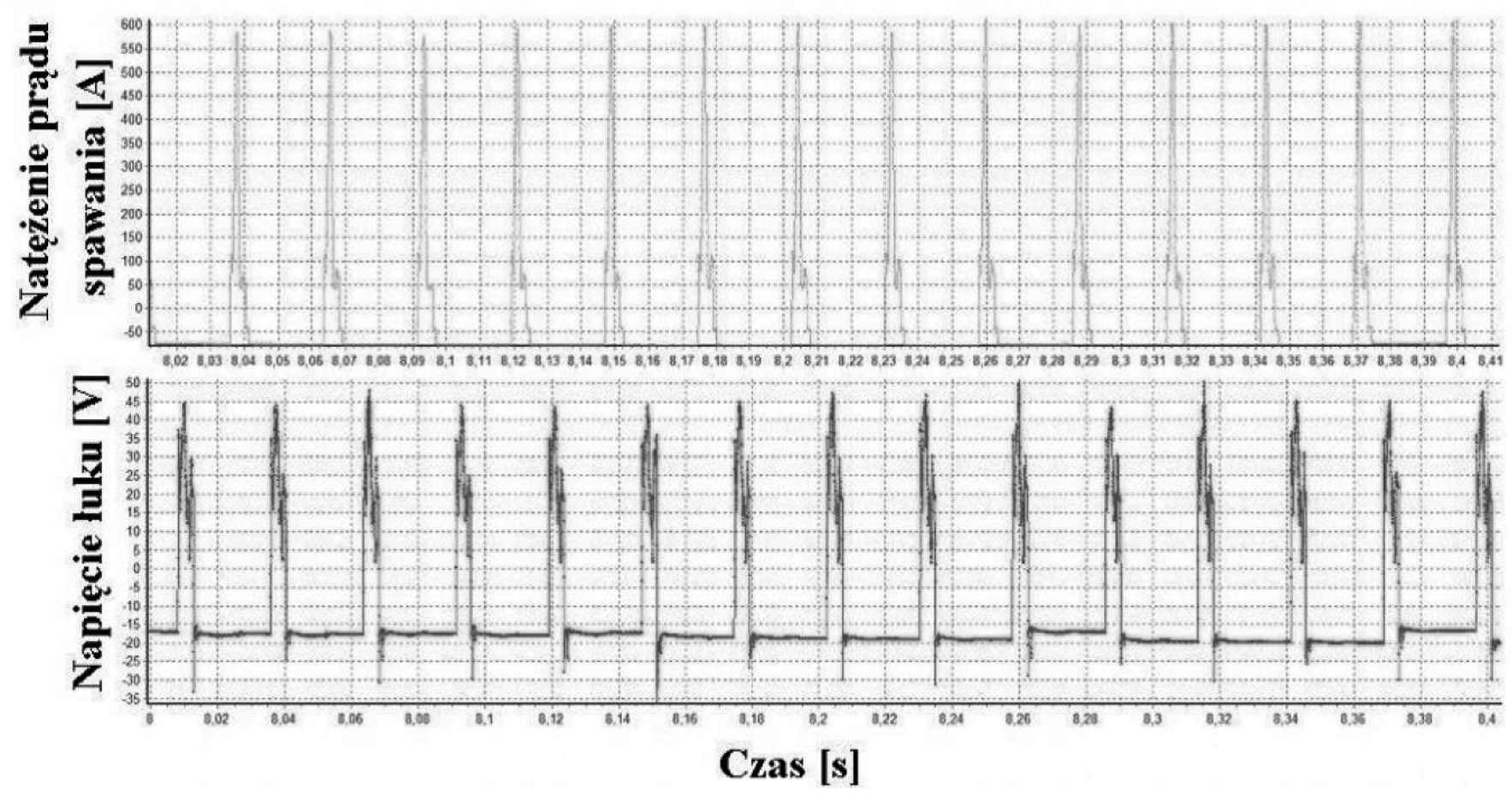

Rys. 2. Rzeczywisty, zarejestrowany przebieg spawania ze zmienną polaryzacją łuku [3]

Fig. 2. Registered real welding process with alternate welding arc polarisation [3] 
panelu sterowania urządzenia Qineo Champ, przy wyborze spawania metodą ColdWeld, regulacji ilości składowej ujemnej dokonuje się przez zmianę parametru AC-Dyn w zakresie bezwymiarowej nastawy od -50 do +50 . Przy czym wartość środkowa (0) odpowiada optymalnie dobranej przez producenta ilości składowej ujemnej. Skrajna wartość nastawy (-50) będzie odpowiadała klasycznemu przebiegowi DC Puls bez zmiany polaryzacji (zerowy udział składowej ujemnej). Natomiast po drugiej stronie skali - przy nastawie $(+50)$ - będziemy mieli do czynienia z przebiegiem o maksymalnie wydłużonym czasem trwania składowej ujemnej, gwarantującym jeszcze stabilny proces palenia się łuku spawalniczego.

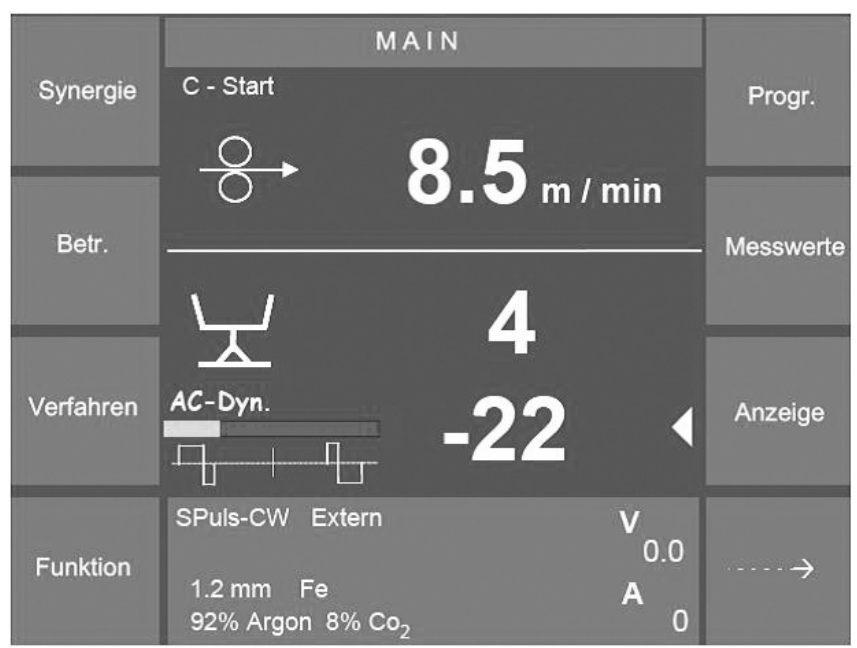

Rys. 3. Przebieg spawania ze zmienną polaryzacją łuku Fig. 3. Welding process with alternate arc polarization

Zmiana parametru AC-Dyn przekłada sie wprost na ilość ciepła wprowadzonego do materiału spawanego oraz na kształt spoiny. Zwiększanie udziału składowej ujemnej będzie powodowało zmniejszenie ilości ciepła wprowadzonego do materiału podstawowego oraz zmniejszenie głębokości wtopienia i uzyskanie większego nadlewu lica spoiny. W ten sposób możemy wpływać na geometrię spoiny lub istotnie zwiększyć wydajność spawania przy zachowaniu tej samej ilości ciepła wprowadzonego do materiału.

\section{Badania}

Proces spawania metodą MIG/MAG ze zmienną polaryzacją łuku spawalniczego został poddany dokładnym badaniom w Zakładzie Spawalnictwa Politechniki Częstochowskiej. Miały one na celu między innymi określenie: wpływu ujemnej biegunowości prądu na ograniczenie ilości ciepła wprowadzonego do złącza spawanego i zwiększenia wydajności spawania oraz możliwości stosowania procesu AC Puls do spawania elementów cienkościennych [4].

Wyniki badań wykazały, że w przebiegu asymetrycznym przez zmianę ilość składowej ujemnej proporcjonalnie maleje ilość ciepła wprowadzonego do spoiny przy zachowaniu tej samej mocy łuku. Zależność ta daje możliwość wpływu na stopień wymieszania materiału podstawowego ze stopiwem oraz zmianę geometrii spoiny. Otrzymane wyniki wskazują na duże korzyści stosowania tej odmiany procesu spawania do cienkościennych elementów.

Autorzy tych badań dokonali porównania prędkości stapiania między procesami spawania: klasycznym zwarciowym DC Standard, DC Puls oraz ze zmienną polaryzacją łuku AC Puls. Ten ostatni wykazuje większe prędkości stapiania w całym zakresie nastaw prądowych w porównaniu z pozostałymi procesami. Ponadto wykazano ścisłą korelację między współczynnikiem balansu (określonym jako pro- centowy udział energii przekazanej do złącza w czasie trwania fazy ujemnej), a współczynnikiem mocy łuku. (rys. 4). Dzięki temu autorzy zaproponowali odmienny sposób wyznaczania podstawowych parametrów spawania: natężenia prądu spawania i napięcia łuku oraz obliczania jego mocy, z uwzględnieniem odpowiednich współczynników określonych dla danego procesu spawania [6]. Ten sposób pozwala na właściwe szacowanie energii liniowej spawania w różnych odmianach procesu MIG/MAG, które ze względu na różne charakterystyki przebiegów prądowo-napięciowych mają różne oddziaływanie cieplne na materiał spawany [4].

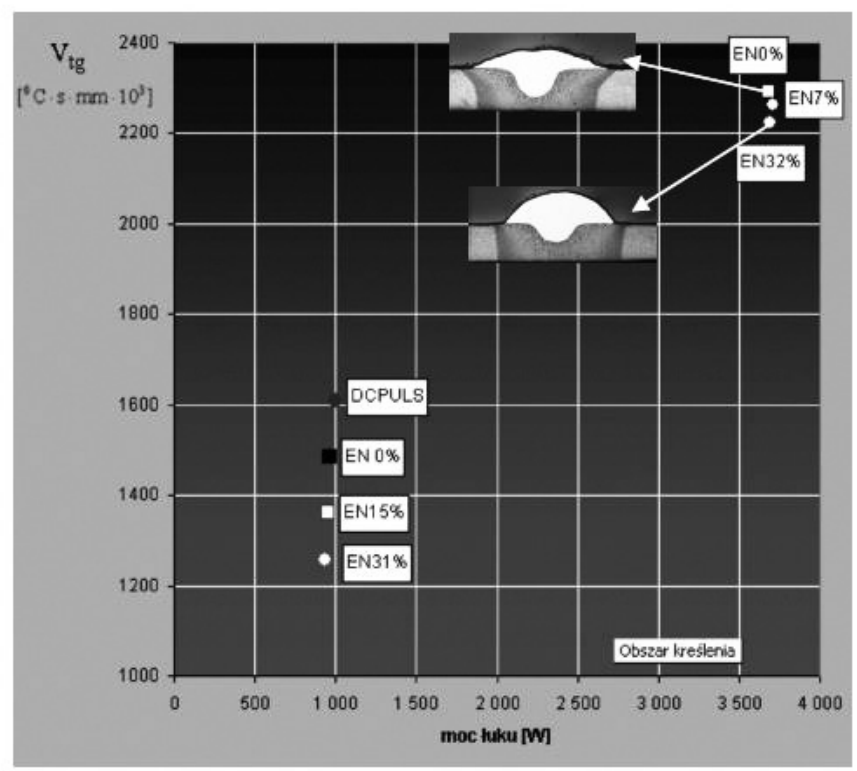

Rys. 4. Wpływ ujemnej biegunowości na stopień nagrzania złącza i geometrię spoiny [4]

Fig. 4. Welding current minus factor impact on heat input and geometry of welding seam [4]

Opisane powyżej zalety spawania metodą ColdWeld doskonale wypełniają oczekiwania stawiane urządzeniom spawalniczym przeznaczonych do zastosowań w lutospawaniu, gdzie istotne jest ograniczenie ilości doprowadzonego ciepła do brzegów łączonych materiałów tak, aby je rozgrzać, a nie stopić. Podobnie wygląda spawanie cienkich blach z powłoką ochronną, w szczególności blach ocynkowanych. Tu z kolei za duża ilość ciepła powoduje intensywne odparowywanie cynku, co prowadzi do powstawania porów i pęcherzy gazowych w lutospoinie oraz zniszczenia warstwy antykorozyjnej.
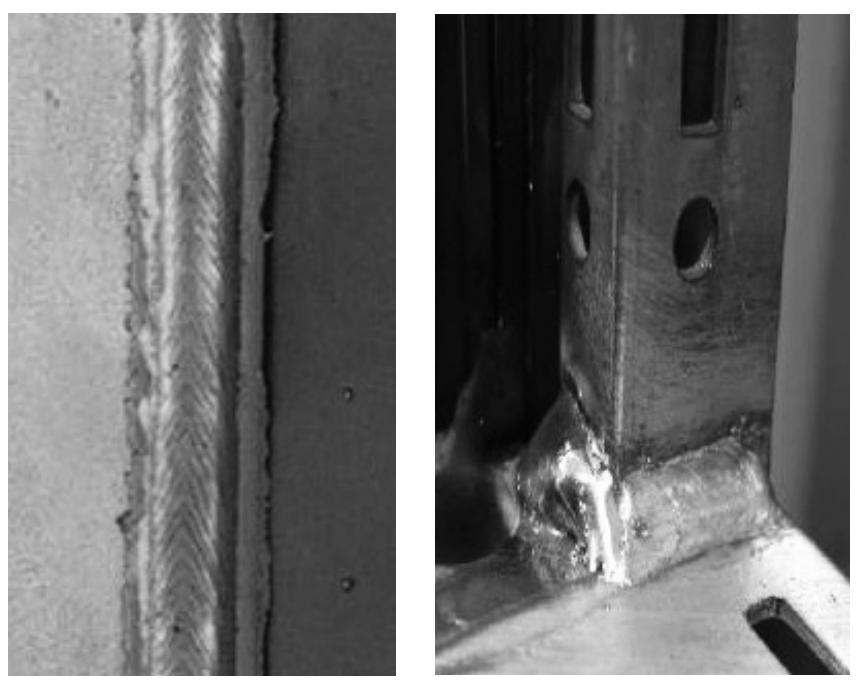

Rys. 5. Przykłady połączeń wykonanych metodą lutospawania z zastosowaniem metody ColdWeld

Fig. 5. Examples of joints made in ColdWeld process and brazing 
W Instytucie Spawalnictwa w Gliwicach, w ramach prowadzonych projektów badawczych, przeanalizowano technologiczne możliwości spawania i lutospawania materiałów konstrukcyjnych z powłokami, przy zastosowaniu innowacyjnych metod spawania ze zmienną polaryzacją łuku [3,7]. Wyniki tych badań wykazały bardzo dobre własności złączy wykonanych z wykorzystaniem procesu ColdWeld przy zmiennej grubości i rodzaju materiałów podstawowych z różnymi powłokami ochronnymi. Ze szczególnym zainteresowaniem przebadano wpływ wartości składowej ujemnej na jakość połączeń spawanych i lutospawanych. Ponadto określono optymalne obszary parametrów spawania dla poszczególnych zadań spawalniczych.

Stwierdzono również bardzo dobre efekty zastosowania tego procesu spawania do złączy niedopasowanych, ze szczelina dochodzącą nawet do $2 \mathrm{~mm}$. Przy różnych rodzajach złączy (zakładkowe, doczołowe, teowe), spawanie metodą ColdWeld wykazało bardzo dobry efekt mostkowania, wysoką estetykę spoin i przede wszystkich odpowiednią

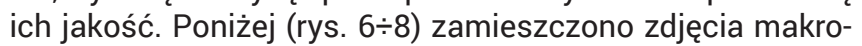
struktury niedopasowanych złączy spawanych wykonanych w Instytucie Spawalnictwa w Gliwicach.

Zarówno badania analityczne przeprowadzone w Politechnice Częstochowskiej jak i technologiczne w Instytucie Spawalnictwa nad procesem spawania ze zmienną

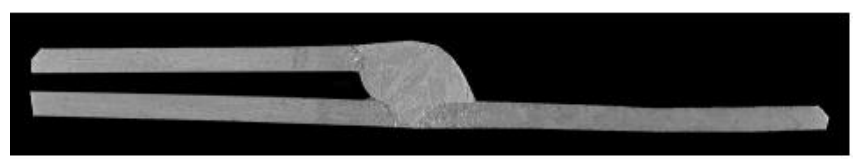

Rys. 6. Widok złącza zakładkowego [3]

Fig. 6. View of lap joint [3]

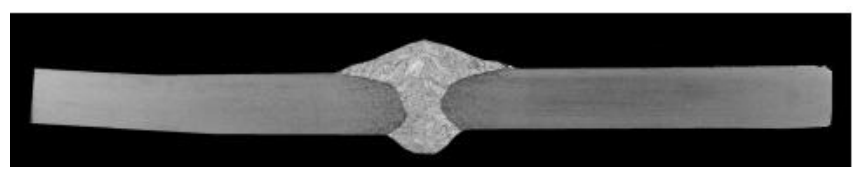

Rys. 7. Widok złącza doczołowego [3]

Fig. 7. View of lap joint [3]

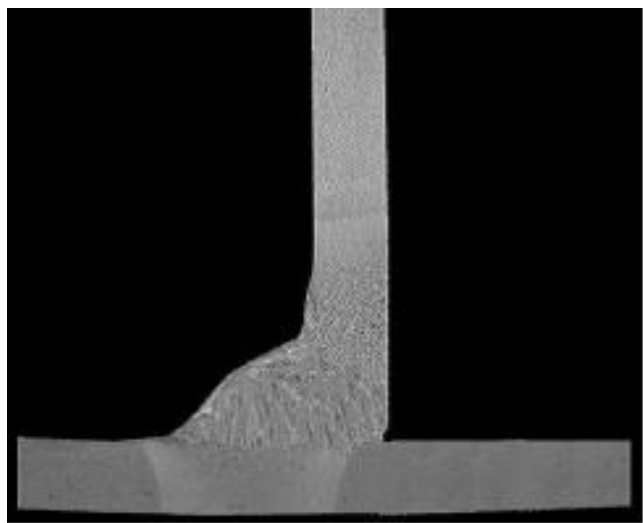

Rys. 8. Widok złącza teowego [3]

Fig. 8. View of T shape joint [3]

polaryzacją łuku, wykazały, że w porównaniu do spawania konwencjonalnego, występuje tu istotnie mniejszy stopień nagrzewania materiału podstawowego oraz mniejsze oddziaływanie ciepła na ten materiał. Metoda ta pozwala na ograniczenie naprężeń i odkształceń spawalniczych, a zatem daje możliwość bezpiecznego jej stosowania dla materiałów wykazujących sie dużą wrażliwością na przegrzanie oraz w procesach łączenia metali, po których oczekuje się niewielkich naprężeń i odkształceń końcowych. Ważną cechą tego procesu jest możliwość kształtowania geometrii spoiny przez zmianą ilości składowej ujemnej.

Warto podkreślić, że proces spawania ColdWeld nie wymaga żadnych specjalnych czy dedykowanych materiałów spawalniczych, dodatków stopowych ani gazów osłonowych. Nie wymaga też stosowania specjalnych uchwytów spawalniczych czy rozbudowanych układów podawania drutu spawalniczego. Może być prowadzony we wszystkich pozycjach spawalniczych, zarówno ręcznie jak i w sposób zautomatyzowany. Ponadto nie jest ograniczony tylko do spawania i lutospawania blach o niewielkiej grubości, ale może być prowadzony w całym zakresie parametrów prądowych dostępnych na urządzeniu Qineo Champ (od 40 do $600 \mathrm{~A})$.

\section{Podsumowanie}

Stosowanie w przemyśle coraz cieńszych i bardziej wytrzymałych materiałów skłoniło producentów urządzeń spawalniczych do wdrożenia nowych technologii łączenia metali, które umożliwiają wydajne wykonanie połączeń spawanych przy zachowaniu minimalnej ilości ciepła wprowadzonego do materiału. Firma Cloos Schweisstechnik, producent systemów Qirox oraz Qineo, która koncentruje się głownie na rozwoju i doskonaleniu produktów dla potrzeb spawalnictwa i robotyzacji procesów spawania, po raz kolejny oferuje kompletny system produkcyjny w pełni odpowiadający współczesnym wyzwaniom technologicznym.

Połączenie zalet procesu spawania ColdWeld z zaletami i możliwościami zrobotyzowanego systemu Qirox (w postaci zaawansowanych i wysoce skutecznych układów śledzenia spoin czy oprogramowania robotów zoptymalizowanego dla zadań spawalniczych) stanowi trafne rozwiązanie dla nowoczesnego przemysłu metalowego. Każde zwiększenie wydajności procesu spawania, a zwłaszcza takie, które zapewni mniejszą ilość ciepła wprowadzanego do materiału spawanego, chroniąc go tym samym przed odkształceniami lub utratą powłoki ochronnej, zostanie zapewne docenione w produkcji seryjnej, gdyż zwiększy produktywność i zminimalizuje koszty produktu końcowego. Powyższe własności mogą znaleźć zastosowanie szczególnie w sektorze motoryzacyjnym, który wymaga wydajnych systemów produkcyjnych, a spawanie zrobotyzowane jest tam standardem.

Te cechy posiada zrobotyzowany system Qirox, wyposażony w urządzenie spawalnicze Qineo Champ, umożliwiający spawanie metodą ColdWeld. 


\section{Literatura}

[1] Dobaj E.: Maszyny i urządzenia spawalnicze, Wydawnictwa Naukowo-Techniczne, Warszawa 1994.

[2] Hackl H., Bidner. G: Wzrost jakości przy tradycyjnym i impulsowym spawaniu metodą MIG/MAG przez wprowadzenie nowej technologii, Biuletyn Instytutu Spawalnictwa, 1993, nr 5, str. 11-13.

[3] Kiszka A., Pfeifer T.: Spawanie cienkich blach stalowych z powłokami ochronnymi metodą MAG prądem o zmiennej biegunowości, Biuletyn Instytutu Spawalnictwa, nr 2, 2012, s. 39-43.

[4] Kudła K., Wojsyk K.: Ocena i sposoby ograniczania ciepła wprowadzanego do złącza w procesach wykorzystujących zmodyfikowane asymetryczne przebiegi prądu impulsowego, Materiały XVI Naukowo-Technicznej Konferencji Spawalniczej, Międzyzdroje 2010, s. 171-180.
[5] Kudła K., Wojsyk K.: Czy sposób doprowadzania ciepła ma istotny wpływ na geometrię spoin?, Biuletyn Instytutu Spawalnictwa Nr 5, 2012, s. 140-144.

[6] Kudła K., Wojsyk K.: Normowana energia liniowa, a ilość ciepła wprowadzanego podczas spawania, Przegląd Spawalnictwa Nr 12, 2010, s. 21-25.

[7] Pikuła J., Mendakiewicz J., Pfeifer T., Wpływ gazu osłonowego na własności połączeń blach ocynkowanych wykonanych metodą lutospawania MIG/MAG prądem o zmiennej biegunowości, Biuletyn Instytutu Spawalnictwa, vol. 58 (1), s. 54-59, 2014. 